\title{
Learning Strategies for Arabic Grammar at the West Sulawesi in Understanding the Heritage Books (A Case Study at Allo Biqar Pambusuang Foundation, Polewali Mandar, West Sulawesi)
}

\author{
Hamzah \\ \{hamzah87_aziz@ymail.com\} \\ Islamic Institute of Darud Da'wah Wal Irsyad (IAI DDI) Polewali Mandar
}

\begin{abstract}
This research aims to uncover the learning strategies applied at the Learning Institute to Read the Heritage Books Allo Biqar Pambusuang Foundation, with sub focus including: what Arabic Grammar learning program, the learning methods and techniques used in learning Arabic Grammar for ability to read the Heritage Books. This research uses qualitative by making case studies. Data collection was carried out through in-depth interview and semistructured techniques, participatory observation and direct observation, and documentation. Data analysis done interactively using techniques recommended by Miles and Huberman in the design of case studies. And for checking the validity of the findings carried out using techniques recommended by Linclon and Guba. While the instruments in this research are the researcher's own with guidance on interviews and observations in the Field. The results of this study indicate that: 1) Learning Arabic Grammar at Allo Biqar Foundation consists of 2 levels, namely the basic level and the level of development. Of the two levels provided 5 learning programs are offered, 3 programs at the basic level, and 2 development level programs. 2) There are 10 methods used respectively with each technique in learning Arabic Grammar at the Allo Biqar Pambusuang Foundation in order to read and understand the Heritage Books; 6 methods at the basic level and 4 methods at the development level.
\end{abstract}

Keywords - Learning Strategies, Teaching Arabic Grammar, Reading Skills, Heritage Books

\section{Introduction}

The orientation of learning in this century has been highly developed, language researchers such as Schunk say that the course of study in this century no longer studies how knowledge is gained, but they are studying how it is built and constructed [1]. Suparno warns that in the last 20 years, the education system in Europe, the United States and Australia has been heavily influenced by a system of learning that is oriented to students. This indicates that studies of both strategies and methods are no longer focused on teaching and material but have shifted to 
student domain [2]. Historically, Sri Utari Subyakto-Nababan points out that humans have always sought better methods of presentation of teaching materials to facilitate a student's work or assignment, and this has been true for a long time now. The changes of presentation from time to time in the teaching methods of language reflect the emphasis of what skills are deemed essential and what language learners must possess. Typically the skills emphasized include those skills of "reading" and "speaking" [3].

Regarding the problem of method, his urgency in a learning is not given that he is essential and determined to achieve a goal. Many researchers have examined the urgency of a method of learning. Ulin Nuha considers the method to be the leading actor of a learning [4]. Uril Baharuddin rates that the success of a learning depends on how well its methods are used [5]. Uno considers that to judge the success of learning the standards are a method. Even optimal learning methods laid at the heart of the learning design [6].

In the past 15 years, Indonesian Arabic learning in grammar in particular on the island of Java has been thriving, marked by the emergence of various methods, concepts and ways to read and understand theheritage books well and efficiently. Like the book Amsilati: Metode Praktis Mendalami al-Qur'an dan Membaca Kitab Kuning, 5 volumes [7]., book 4 Langkah Membaca \& Menerjemah Kitab Gundul Metode Assasakiy [8]., book Pintar Membaca Arab Gundul dengan Metode Hikari [9]., book Cara Cepat Membaca \& Menerjemah Kitab Gundul Metode Al-Ankabut [10]., book Cepat Membaca Kitab Gundul Teknik 234 (Dji Sam Soe) [11]., and book Al-Miftah lil Ulum: Mudah Belajar Membaca Kitab, 4 volumes [12].

The developments also occurred on the island of Sulawesi, especially in West Sulawesi, located in the village of Pambusuang, Balanipa, Polewali Mandar. A village of religion, the town of santri and was the center for development and study of Arabic grammar for being able to read and understand heritage books, and it has existed from the 19th century to this day. And today, a foundation standing in the rural centre of Pambusuang still exists to build and develop sanitians to read a heritage book and study it for themselves in a relatively short period of two to three months with the strategies applied, the Allo Biqar Pambusuang Foundation [13]. It aims to uncover the Arabic grammatical learning program taught in the Allo Biqar Pambusuang Foundation and the learning structure (methods and techniques) applied in teaching Arabic grammar to understand the heritage books well and efficiently.

\section{Methods}

This research uses qualitative approach by making case studies. Data collection was carried out through in-depth interview and semi-structured techniques, participatory observation and direct observation, and documentation. Data analysis done interactively using techniques recommended by Miles and Huberman in the design of case studies, including data condensation after data collection, then data presentation and conclusion [14].

As a case study design, data collection in this research was carried out in three ways, namely in-depth interviews (of students, teachers at the Allo Biqar Pambusuang Foundation and local communities and other senior figures), observation (of the existing learning process in the field), and documentation (of textbooks used in learning activities in the field, structures, drawings and others).After the data collection is done, the researcher condenses the data based on the data requirements to answer the problem in the problem formulation or in the research question,then the data are presented based on the needs of each discussion based on the problems that have been formulated. After that, conclusions are made in each discussion whose 
results will be discussed and analyzed by correlating theories of learning strategies and types based on their classification recommended by Iskandarwassid and Dadang Sunendar in his book "Strategi Pembelajaran Bahasa" to find formal findings in this study.

And for checking the validity of the findings carried out using techniques recommended by Linclon and Guba [15]. While the instruments in this research are the researcher's own with guidance on interviews and observations in the Field.

\section{Result and Discussion}

After doing some research for the past seven months from Juny to July 2017 and than from October 28, 2018 to March 42019 in the AlloBiqarPambusuang Foundation with collecting data through interviews, observation and documentation, and the results of the study based on the problem formulas under study suggest that the study in the AlloBiqarPambusuang Foundationconsists of two levels, the basic level and level of development. Of these two levels are five learning programs taught. Three learning programs on the basiclevel, and two learning programs on the level of development. Yet the methods and techniques used in teaching Arabic grammar to understand the manual have found 10 methods with each technique applied in the field.

The Arabic Grammar Learning Program, Its Teaching Methods and Techniques

For the basic level, are taught three Arabic grammar programs at the Allo Biqar Pambusuang Foundation, namely: sharaf learning program (sharaf ghalappo), the nahwu learning program (nahwu hang book) and the practice analyze learning program (analyze and decipher words).

Learning at this basic level is simply to teach students the basics of Arabic grammar that leads them in order to understand word change, function of the word in a sentence and line change each word in a sentence. And on this program the punishment and reward systems haven't implemented.

Sharaf Learning Program

The basic materials of this program is about word. So the program is to give information and understanding about the change of a word and the establishment of both the three letters and the supposed supposed to have an extra letter. And the way to teach it is through a rote whose percentage of wazan has memorized while $15 \%$ know the theory. As for the rule book used is the ghalappo tashrif book. Whereas the number of meetings is 30 times within 4 to 7 days with an intensity of meetings 4-5 times a day.

The methods and techniques used in teaching the material in this program are: 1) memorization methods with singing techniques and drill exercises, 2) sorogan methods with independent and individual learning techniques, 3) mattale' methods with independent learning techniques, both individual learning and group learning, 4) inductive methods with techniques interactive, 5) deductive methods with interactive techniques, and 6) active learning method with peer learning techniques.

Nahwu Learning Program

The basic material of this program is about the sentence. So the program is intended to provide information and understanding of the fundamentals of Arabic grammar both in terms of marfuat, manshubat and majrurat, and is briefly given an example of how to decipher and analyze a word in a sentence each theme taught. Her learning stood in the opposite percentages of $85 \%$ carving the basis of Arabic grammar materials, while $15 \%$ of the memorization and the 
practice of secting and analyzing sentences. As for the rule book used is the book of nahwu hung. Whereas the number of meetings is 30 times within 7 to 12 days with an intensity of meetings $4-5$ times a day.

The methods and techniques used in teaching the material in this program are: 1) inductive methods with interactive techniques, 2) deductive methods with interactive techniques, 3) grammar and translation methods with analytical techniques, 4) generative learning methods with comparison techniques, 5) active learning method with peer learning techniques.

Analizing word learning program (analyze and decipher words)

The basic material of the program was the practice of analyzing and decoding thematic literature compiled from the book of al akhlaq lil banin volume 2 . The program aims to teach learners how to decipher and analyze the function of the word in each sentence and to determine the extent to which students' ability to understand Arabic grammar is learned by analyzing and decoding the function of the word in a sentence so that they can read and understand the meaning of Arabic literature. The guide book used was a thematically composed book as many as 15 topics from the book of al akhlaq lil banin volume 2 . As for the number of meetings 30 times within 7 to 12 days with an intensity of meetings 4-5 times a day.

The methods and techniques used in teaching the material in this program are: 1) grammar and translation methods with analytical techniques, 2) mattale' methods with independent learning techniques, both individual learning and group learning, and 3) active learning method with peer learning techniques.

While for development levels there are two Arabic grammar learning programs, namely: The Advanced Arabic grammar learning program (using the book nahwu wadhih volume 2 and 3 ) and the learning program to read heritage books (using nonwritten books such as the book almuawanah, tanqihulqaul, durratunnasihin, fathulmuin and other books). And on this program there has been the system punishment and reward asa form of discipline and a way for a teacher to assess a student's ability to read arabic texts.

Advanced Arab grammatical material learning program

This program continued from basic Arabic grammar materials using the book of nahwu wadhi volume 2 and 3 . The program is intended to solidify learners' understanding of Arabic grammar (nahwu and sharaf) so as to know and read the heritage book properly and independently. The number of meetings in the program is 81 times 16-20 days, with meeting intensity 4-5 meetings a night a day.

The methods and techniques used in teaching the materials in this program are: 1) the inductive deductive method with discussion and interactive techniques, 2) the mattale' method with independent learning techniques both individual learning and group learning, 3) the reading method with the reader's number down technique.

Heritage Book learning program

This program is the final program of Arabic grammar study at the Allo Biqar Pambusuang Foundation. The material of the program was reading the prescribed book and each student at the beginning of the meeting was required to read several lines with certain stipulations that resulted in the execution of punishment if violated of the rule of literature. It aims to see how well learners are able to apply their learning in the form of reading a book out of the bald head. As for the commonly used book is al-muawanah, tanqihulqaul, durratunnasihin, nasaihulibad, fathulqarib, fathulmuin, and other books. The learning period of the program is approximately 30-40 days with a meeting intensity of 4-5 meetings a night a day.

The methods and techniques needed to teach the material in this program are: 1) the wetonan or bandongan method with lecture and discussion techniques, 2) the mattale' method 
with independent learning techniques both individual learning and group learning, 3) the reading method with the reader's number down technique.

To find out what learning strategy is used in teaching Arabic grammar at the Allo Biqar Pambusuang Foundation, researchers try to discuss the results that researchers found in the upper results by identifying the different learning strategies based on the classified learning strategies given by Iskandarwassid and Dadang Sunendar in his book Strategi Pembelajaran Bahasa (language learning strategy).

The definition of the macro strategy held by researchers in this case is the definition of a macro strategy as held by J.R. David (1976), Dick and Carey (1985), Kemp (1995), Wina Sanjaya (2006), Hamzah B. Uno (2007), Munif Hudhair (2013) and friends who call it a strategic plan of a series of activities designed to accomplish a specific educational goal, Meaning that strategy refers to a plan of operation achieve something [16]. Munif Hudhair points out that in this case two fundamental ideas conceived by a strategy: method and technique [17]. Hierarchical, therefore, it may be assumed that strategy was more prevalent than method and technique.

The types of learning strategies described by Iskandarwassid and Dadang Sunendar based on the following chart [18]:

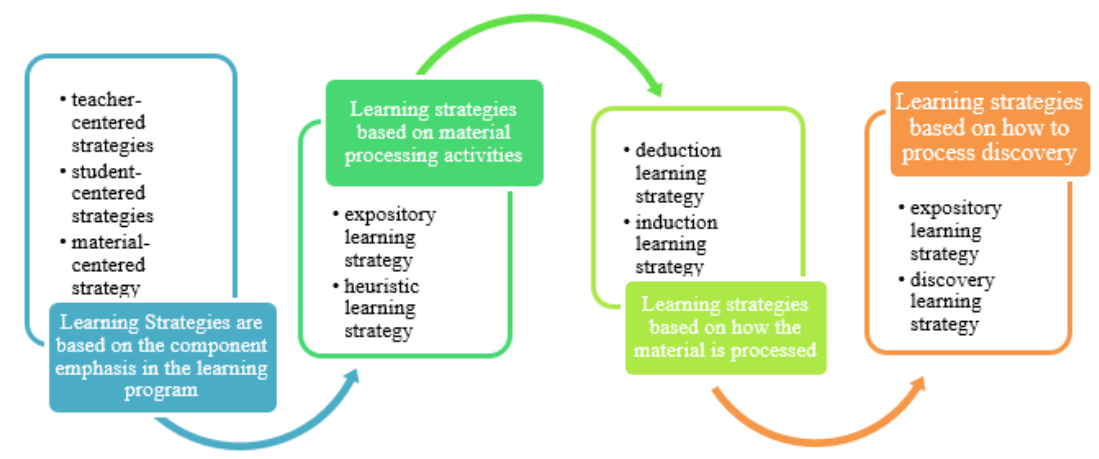

Fig. 1. Types of learning strategies based on their classification

Here's the learning strategy identification table based on the methods and techniques used in the Allo Biqar Pambusuang Foundation in teaching Arabic grammar to understand a heritage books that has created utilities based on the types of learning strategies based on the classifieds.

Table 1. Identification results of types of learning strategies based on their classification at Allo Biqar Foundation

\begin{tabular}{|c|c|c|c|c|c|c|c|c|c|c|c|}
\hline \multirow[t]{3}{*}{ No } & \multirow[t]{3}{*}{ Method (Technique) } & \multirow{3}{*}{$\begin{array}{l}\text { Teaching } \\
\text { Material } \\
\text { Program }\end{array}$} & \multicolumn{9}{|c|}{ Jenis-jenisStrategiPembelajaran } \\
\hline & & & \multicolumn{3}{|c|}{$\begin{array}{l}\text { Based on the } \\
\text { emphasis of } \\
\text { components in the } \\
\text { learning program }\end{array}$} & \multicolumn{2}{|c|}{$\begin{array}{l}\text { Based on } \\
\text { material } \\
\text { processing } \\
\text { activities }\end{array}$} & \multicolumn{2}{|c|}{$\begin{array}{l}\text { Based on } \\
\text { how the } \\
\text { material is } \\
\text { processed }\end{array}$} & \multicolumn{2}{|c|}{$\begin{array}{l}\text { Based on } \\
\text { how to } \\
\text { process } \\
\text { discovery }\end{array}$} \\
\hline & & & $\begin{array}{l}\text { Tea } \\
(1)\end{array}$ & $\begin{array}{l}\text { Stu } \\
(2)\end{array}$ & $\begin{array}{c}\text { Mat } \\
(3)\end{array}$ & $\begin{array}{l}\operatorname{Exp} \\
(4)\end{array}$ & $\begin{array}{l}\mathrm{Heu} \\
(5)\end{array}$ & $\begin{array}{l}\text { Ind } \\
(6)\end{array}$ & $\begin{array}{l}\text { Ded } \\
(7)\end{array}$ & $\begin{array}{l}\operatorname{Exp} \\
(8)\end{array}$ & $\begin{array}{l}\text { Dis } \\
(9)\end{array}$ \\
\hline 1 & $\begin{array}{l}\text { Memorization (singing } \\
\text { and drill exercises) }\end{array}$ & 1 & - & $\sqrt{ }$ & $\sqrt{ }$ & - & $\sqrt{ }$ & - & $\sqrt{ }$ & - & $\sqrt{ }$ \\
\hline 2 & Sorogan (individual) & 1 & - & $\sqrt{ }$ & - & - & $\sqrt{ }$ & - & $\sqrt{ }$ & - & $\sqrt{ }$ \\
\hline 3 & $\begin{array}{l}\text { Mattale' (individual } \\
\text { andgroup) }\end{array}$ & $1,2,3,4,5$ & - & $\sqrt{ }$ & - & - & $\sqrt{ }$ & $\sqrt{ }$ & $\sqrt{ }$ & - & $\sqrt{ }$ \\
\hline
\end{tabular}




\begin{tabular}{|c|c|c|c|c|c|c|c|c|c|c|c|}
\hline \multirow[t]{3}{*}{ No } & \multirow[t]{3}{*}{ Method (Technique) } & \multirow{3}{*}{$\begin{array}{l}\text { Teaching } \\
\text { Material } \\
\text { Program }\end{array}$} & \multicolumn{9}{|c|}{ Jenis-jenisStrategiPembelajaran } \\
\hline & & & \multicolumn{3}{|c|}{$\begin{array}{l}\text { Based on the } \\
\text { emphasis of } \\
\text { components in the } \\
\text { learning program }\end{array}$} & \multicolumn{2}{|c|}{$\begin{array}{l}\text { Based on } \\
\text { material } \\
\text { processing } \\
\text { activities }\end{array}$} & \multicolumn{2}{|c|}{$\begin{array}{l}\text { Based on } \\
\text { how the } \\
\text { material is } \\
\text { processed }\end{array}$} & \multicolumn{2}{|c|}{$\begin{array}{l}\text { Based on } \\
\text { how to } \\
\text { process } \\
\text { discovery }\end{array}$} \\
\hline & & & $\begin{array}{l}\text { Tea } \\
(1) \\
\end{array}$ & $\begin{array}{l}\text { Stu } \\
(2)\end{array}$ & $\begin{array}{c}\text { Mat } \\
(3)\end{array}$ & $\begin{array}{l}\operatorname{Exp} \\
(4)\end{array}$ & $\begin{array}{c}\mathrm{Heu} \\
(5)\end{array}$ & $\begin{array}{l}\text { Ind } \\
(6)\end{array}$ & $\begin{array}{c}\text { Ded } \\
(7) \\
\end{array}$ & $\begin{array}{l}\text { Exp } \\
(8)\end{array}$ & $\begin{array}{l}\text { Dis } \\
(9)\end{array}$ \\
\hline 4 & $\begin{array}{c}\text { Active Learning (Peer } \\
\text { learning) }\end{array}$ & $1,2,4$ & - & $\sqrt{ }$ & - & - & $\sqrt{ }$ & $\sqrt{ }$ & $\sqrt{ }$ & - & $\sqrt{ }$ \\
\hline 5 & Inductive (Interactive) & $1,2,3$ & $\sqrt{ }$ & - & - & $\sqrt{ }$ & - & $\sqrt{ }$ & - & $\sqrt{ }$ & - \\
\hline 6 & $\begin{array}{c}\text { Deductive } \\
\text { (Interactive) }\end{array}$ & $1,2,3$ & $\sqrt{ }$ & - & - & $\sqrt{ }$ & - & - & $\sqrt{ }$ & $\sqrt{ }$ & - \\
\hline 7 & $\begin{array}{c}\text { Grammar and } \\
\text { Translation (analyze) }\end{array}$ & 3 & - & $\sqrt{ }$ & - & - & $\sqrt{ }$ & $\sqrt{ }$ & - & - & $\sqrt{ }$ \\
\hline 8 & $\begin{array}{l}\text { Generative Learning } \\
\text { (Comparison) }\end{array}$ & 2 & $\sqrt{ }$ & - & - & $\sqrt{ }$ & - & - & $\sqrt{ }$ & - & $\sqrt{ }$ \\
\hline 9 & $\begin{array}{l}\text { Reading (Reader's } \\
\text { number down) }\end{array}$ & 4,5 & - & $\sqrt{ }$ & $\sqrt{ }$ & - & $\sqrt{ }$ & $\sqrt{ }$ & - & - & $\sqrt{ }$ \\
\hline \multirow[t]{2}{*}{10} & Wetonan/Bandongan & 5 & $\sqrt{ }$ & - & $\sqrt{ }$ & $\sqrt{ }$ & - & - & $\sqrt{ }$ & $\sqrt{ }$ & - \\
\hline & & & 4 & 6 & 3 & 4 & 6 & 5 & 7 & 3 & 7 \\
\hline
\end{tabular}

Note:1 Sharf Materials, 2 Nahwu Materials, 3 Materil'rab Training, 4 NahwuWadhiMaterials Vol. II \& III, 5 Bare book

(1) Teacher, (2) Student, (3) Materials, (4) Expository, (5) Heuristics, (6) Induction, (7) Deduction, (8) Expository, (9) Discovery.

Based on the above identification chart, It showed that the learning strategy applied to teaching Arabic grammar at The Allo Biqar Pambusuang Foundation is a learning strategy that focuses on student (student-centered strategies) based on results on component emphasis in learning programs supported by 6 learning methods that are centered on students. This can also be seen in the material processing activites section with 6 methods and how to process discovery section with the support of 7 methods all of which are oriented to the activation of the learner in processing and processing of learning. The two sections support the first part and affirm that the Arabic grammar learning orientation at the Allo Biqar Pambusuang Foundation is centers on learning.

\section{Conclusion}

Based on data exposure, identification and analysis in the discussion section, researchers concluded that there are 5 Arabic grammar programs taught to the Allo Biqar Pambusuang Foundation as a whole in two levels ( 3 programs at the basic level and 2 programs at the development level) that are all intensive. While the methods and techniques used in teaching Arabic grammar there are 10 methods (6 methods at the basic level and 4 methods at the development level) that all based on identification and domination of the type of learning strategy based on their classification is student oriented and centered. 


\section{References}

[1] D. H. Schunk, Learning Theories an Educational Perspective (Sixth Edition ed.). (R. F. Eva Hamdiah, Trans.), Sixth. Yogyakarta: Pustaka Pelajar, 2012.

[2] Hamzah, "Konstruktivisme dan Implikasinya dalam Pembelajaran Bahasa Arab," in Prosiding KONASBARA IV: Kreatifitas dan Inovasi dalam Pembelajaran Bahasa Arab di Indonesia, 2018, pp. 117-118.

[3] S. U. Subyakto-Nababan, Metodologi Pengajaran Bahasa. Jakarta. Jakarta: Gramedia Pustaka Utama, 1993.

[4] U. Nuha, Ragam Metodologi \& Media Pembelajaran Bahasa Arab (Super Efektif, Kreatif dan Inovatif). Yogyakarta: DIVA Press., 2016.

[5] U. Baharuddin, Maharat al-Tadris: Nahwa I'dad Mudarris al-Lughah al-'Arabiyah al-Kafi. Malang: UIN Maliki Press, 2011.

[6] H. B. Uno, Model Pembelajaran: Menciptakan Proses Belajar Mengajar yang Kreatif dan Efektif. Jakarta: Bumi Aksara, 2007.

[7] T. Hakim, Amsilati: Metode Praktis Mendalami al-Qur'an dan Membaca Kitab Kuning. Jepara: Al-Falah Offset, 2003.

[8] A. H. Salsabila, 4 Langkah Membaca \& Menerjemah Kitab Gundul Metode Assasakiy. Bekasi: Ukhwatuna., 2010.

[9] A. Purwanto, Pintar Membaca Arab Gundul dengan Metode Hikari. Bandung: Mizania, 2010.

[10] A. Syifa, Cara Cepat Membaca \& Menerjemah Kitab Gundul Metode Al-Ankabut. Yogyakarta: Media Hidayah., 2011.

[11] A. Haris, "Cepat Membaca Kitab Gundul Teknik 234 (Dji Sam Soe)," Universitas Islam Negeri Maliki Malang, 2013.

[12] B. P. Sidogiri, Al-Miftah lil Ulum: Mudah Belajar Membaca Kitab. Pasuruan: Pustaka Sidogiri, 2016.

[13] A. H. Rasyid, "Preliminary Interview. (Hamzah, Interviewer)."

[14] Emzir, Metodologi Penelitian Kualitatif: Analisis Data. Jakarta: Rajawali Pers, 2016.

[15] M. Ainin, Metodologi Penelitian Bahasa Arab. Malang: CV. Bintang Sejahtera., 2013.

[16] W. Sanjaya, Strategi Pembelajaran: Berorientasi Standar Proses Pendidikan. Jakarta: Kencana, 2006.

[17] M. H. Al-Dhawiy, Al-Nadhzariyah al-Binaiyyah wa Tathbiquha fi Tadris al-Lughah al'Arabiyyah. Riyadh: Al-Hamidhiy, 2013.

[18] D. S. Iskandarwassid, Strategi Pembelajaran Bahasa. Bandung: PT. Remaja Rosdakarya, 2008. 